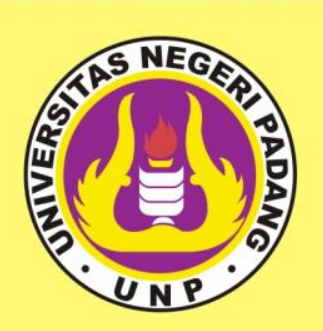

PROCFATN

INTERNATIONAL SEMINAR

ON LANGUAGES AND ARTS

(ISLA)-5

Faculty of Languages and Arts

\title{
Universitas Negeri Padang
}

Padang, 19-20 October 2016

\section{Theme:}

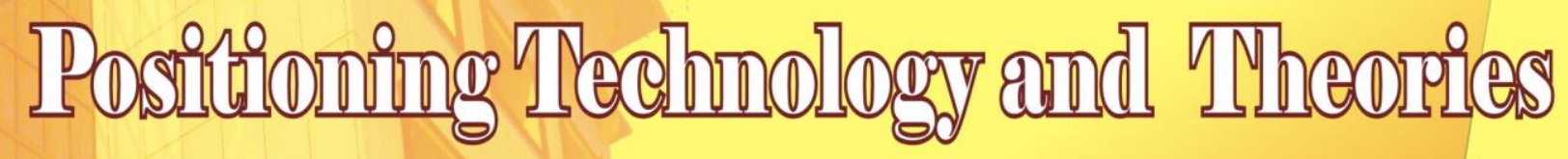

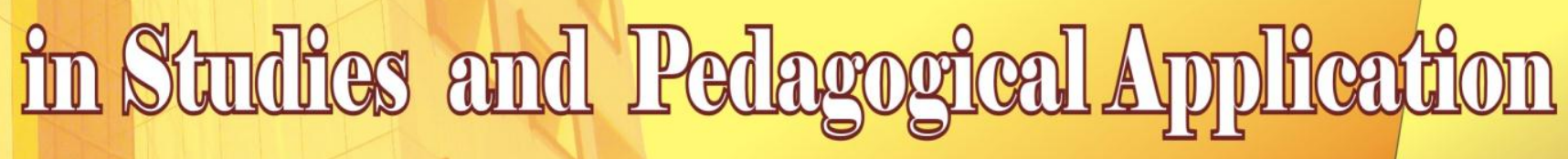

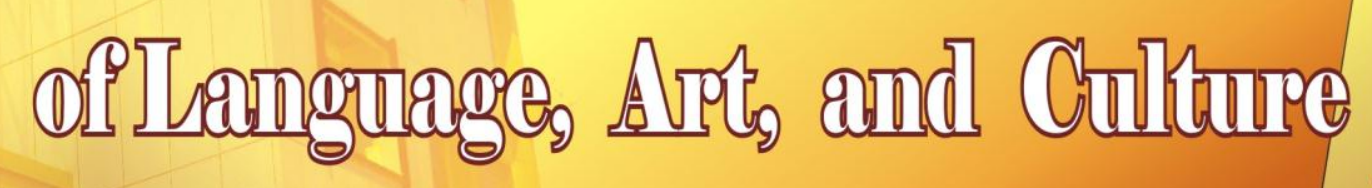

E.6ी: Wan Ahmad Jacfor Wom Wahavo Abdulcader Mo Ayo Nooshi Uda

M. Zaim Jufrizal Zulfadhli Yos sudarman

ISBN: 978-602-73773-3-2 
Proceeding

\title{
INTERNATIONAL SEMINAR ON LANGUAGES AND ARTS (ISLA)-5
}

Faculty of Languages and Arts

Universitas Negeri Padang

\begin{abstract}
Theme:
Positioning Technology and Theories in Studies and Pedagogical Application of Language, Art, and Culture
\end{abstract}

Editors:

Wan Ahmad Jaafar Wan Yahaya : Universiti Sains Malaysia Naoshi Uda : Waseda University, Japan

Abdulcader M. Ayo. : Mindanao State University, Philippines Indrayuda : Universitas Negeri Padang, Indonesia M. Zaim : Universitas Negeri Padang, Indonesia Jufrizal : Universitas Negeri Padang, Indonesia Zulfadhli : Universitas Negeri Padang, Indonesia Yos Sudarman : Universitas Negeri Padang, Indonesia

Padang, Indonesia

19-20 October 2016

Faculty of Languages and Arts

Universitas Negeri Padang 
Fakultas Bahasa dan Seni Universitas Negeri Padang (FBS UNP)

Jalan Belibis Air Tawar, Padang - Sumatera Barat 25131 Indonesia

Telp. (0751) 7053363

http://fbs.unp.ac.id

\section{CFBS UNP 2016}

This book is in copyright. Subject to statutory exception

and to the provision of relevant collective licencing agreement, no reproduction of any part may take place without

the written permission of FBS UNP.

First Published 2016

All rights reserved. No part of this publication may be reproduced, store in a retrieval system, or transmitted, in any form or by any means, without the prior permission in writing of FBS UNP, or as expressly permitted by law, or under term agreed with the appropriate repographics rights organization. Enquiries concerning reproduction outside the scope of the above should be sent to the FBS UNP at the address above. You must not circulate this book in any other binding or cover and you must impose the same condition on any acquirer.

FBS UNP has no responsibility for the presistence or accuracy of URLs for external or third-party internet.

Web sites refered to in this publication and does not quanrantee that any content on such web sites is, or will remain, accurate or appropriate.

\section{PROCEEDING INTERNATIONAL SEMINAR ON LANGUAGES AND ARTS (ISLA)-5}

Edited by
: Wan Ahmad Jaafar Wan Yahaya

: Naoshi Uda

Abdulcader M. Ayo

: M. Zaim

: Indrayuda

Jufrizal

Zulfadhli

Yos Sudarman

Lay Out \& Cover Design $\quad$ : Yos Sudarman

Publisher

Printed by
: FBS UNP

e-mail: info@fbs.unp.ac.id

: Sukabina

Jl. Prof. Dr. Hamka No. 29 Tabing Padang

Telp. (0751) 7055660

ISBN: 978-602-73773-3-2 


\section{FOREWORDS}

On behalf of the committee, please allow us to say Welcome to The Fifth International Seminar on Languages and Arts (ISLA)-5, in Padang, West Sumatera. We do expect that everything is all right and our activities run well. This is the fifth one of the international seminar annually held by Faculty of Languages and Arts, Universitas Negeri Padang. It is highly believed that all members of committee and editors, as well had worked hard to read and review the papers before they were printed in the form this Proceeding. Now, it is the time for us to serve with the proceeding in order that our hard works can be read, learnt, and scientifically criticized, then. Have this proceeding help you well!

We know that the scientific-academic responsibility should be practically actualized in order that the quick development of technologies and theories on language, art, and culture are useful academic and humanistic affairs. Faculty of Languages and Arts, Universitas Negeri Padang believes that the answer for the responsibility should be drawn based on relevant academic-scientific works. Accordingly, it is on the right 'line' to have scientific-academic information and discussion on how to bring the technologies and theories of language, art, and culture into further researches and pedagogical applications by means of specific topics presented in the formal discussion and seminar. These are all essential and useful to build humanistic characters and honest-civil societies in this modern-global era. Therefore, Faculty of Languages and Arts, Universitas Negeri Padang, intentionally organizes The $5^{\text {th }}$ International Seminar on Languages and Art (ISLA-5) under the theme: "Positioning Technology and Theories in Studies and Pedagogical Application of Language, Art, and Culture". This international seminar aims at exploring, describing, informing, and promoting the appropriate uses of modern technologies and current theories in studies and pedagogical application of language, art, and culture. In addition, the seminar is also supposed to discuss and to draw the recommendations for better uses and appropriate application of technologies and theories in the qualified researches and in the learning on language, art, and culture.

The steering and organizing committee had kindly invited speakers for plenary sessions and had received and selected papers presented for parallel sessions from abroad and many institutions in Indonesia. We do warmly appreciate all speakers and would like to thank all participants who are attending and actively participating in this two-day seminar. This academic works and seminar cannot run well without your valuable contribution, active participation, and critical-argumentative ideas. We would like to inform you also that this seminar is one of the activities held as the Dies Natalie ceremonies in 2016. Thus, we would like to thank Rector and leaderships of Universitas Negeri Padang for valuable helps and motivation given. In addition, a lot of thank is addressed to the leadership of Bank Nagari, PT Semen Padang, PT Adhi Karya, and other sponsors which have particular and significant helps for the success of this seminar.

To all of you, once again, thank you very much for everything and have a nice seminar in this town, Padang, the capital of West Sumatera, the mother land of Minangkabaunese!

Padang, 19 October 2016

The Organizing Committee

Chairman,

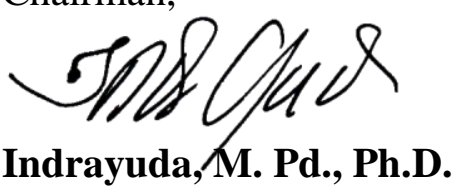




\section{TABLE OF CONTENTS}

FOREWORDS

Page

TABLE OF CONTENTS

\section{A. Keynote Speakers}

1. POSITIONING TECHNOLOGY AND THEORIES IN STUDIES

AND PEDAGOGICAL APPLICATION OF LANGUAGE, ART, AND CULTURE

Prof. Wan Ahmad Jaafar Wan Yahaya, Ph.D. and Balakrishnan Mulandy, Ph.D.

Universiti Sains Malaysia

2. OVERCOMING DUALISM AND EXPANDING THE DOMAIN OF ARCHITECTURE WITH ALGORITMIC DESIGN METHOD

Prof. Dr. Naoshi Uda, M.Eng.

Waseda University, Japan

3. POSITIONING TECHNOLOGY AND THEORIES IN STUDIES

AND PEDAGOGICAL APPLICATION IN LANGUAGE, ART,

AND CULTURE IN PHILIPPINE EDUCATION SYSTEM

Prof. Abdulcader M. Ayo, Ph.D.

Mindanao State University, Philippines

4. THE IMPACTS OF MULTIMODALITY ON LISTENING COMPREHENSION SKILLS:

VOCABULARY ACQUISITION AND CONTENT COMPREHENSION

Prof. Dr. Tengku Silvana Sinar, M.A., Ph.D.

University of Sumatera Utara, Indonesia

$30-36$

5. LANGUAGE AND ART TECHNOLOGY-BASED EDUCATION

IN THE INDONESIAN CONTEXT

Prof. Fuad Abdul Hamied, Ph.D.

Universitas Pendidikan Indonesia, Bandung

6. NEW AESTHETICS AND ITS PEDAGOGICAL CONSEQUENCES

Prof. Dr. Bambang Sugiharto

Universitas Parahyangan, Indonesia

7. THE FORMALITY OF VERBAL CONSTRUCTIONS WITH SERIAL VERB

IN MINANGKABAUNESE: The Case of Bae $+V$ and Kanai $+V^{l}$

Prof. Dr. Jufrizal, M.Hum.

Universitas Negeri Padang, Indonesia.

\section{B. Paralel Speakers}

8. THE USAGE OF DETAILED IMAGINATION ON STUDYING VOCAL ETUDES

A. Gathut Bintarto T.

Indonesian Institute of The Arts, Yogyakarta, Indonesia .

9. APPLICATION OF SEMIOTICS TO INTERPRETING CULTURAL VALUES

IN THE CLASSIC STORY

Abdurrahman and Zulfadhli

Universitas Negeri Padang, Indonesia

$62-70$ 
10. THE USE OF LEARNING MATERIALSIN THE FORM OF VIDEO IN LEARNING DANCE Afifah Asriati

Universitas Negeri Padang, Indonesia.

11. LOCAL WISDOM CONTENT IN MODERN SHORT STORIES

WRITTEN BY MINANGKABAU AUTHORS

Agustina and Yasnur Asri

Universitas Negeri Padang, Indonesia

12. MALCOLM BRADBURY'S WORKS AS POSTMODERN SATIRE

Andhini Rengganis

Universitas Padjajaran, Bandung, Indonesia

90-94

13. THE ROLE OF TECHNOLOGY IN TEACHING LISTENING

Aryuliva Adnan

Universitas Negeri Padang, Indonesia

$95-100$

14. LUAMBEK: A DIALECTIC BETWEEN LOCAL CULTURE AND SYATTARIANISM

Darmawati

Universitas Negeri Padang, Indonesia

$101-106$

15. LEARNING BASED ON THE CULTURE WITH ANIMATION FILM MEDIA AS EFFORTS TO INCREASE INDONESIAN LEARNING IN JUNIOR HIGH SCHOOL

Dina Ramadhanti

STKIP PGRI Sumatera Barat, Indonesia

$107-111$

16. UTILIZATION OF TELEVISION PROGRAMS AND GAME

AS A MEDIUM OF LEARNING FOR IMPROVING ASPECTS OF LANGUAGE SKILLS

Diyan Permata Yanda

STKIP PGRI West Sumatra, Indonesia

$112-116$

17. THE USES OF MODERN TECHNOLOGY IN SELECTING MEDIA AND MATERIALS

FOR TEACHING ENGLISH AS A FOREIGN LANGUAGE

Effendy Gultom

University of Riau, Indonesia

$117-122$

18. READER RESPONSE AS AN ENTRY POINT

INTO LITERARY APPRECIATION AND CREATION

Ekarini Saraswati

University of Muhammadiyah Malang, Indonesia

$123-128$

19. NEED ANALYSYS: ESP SYLLABUS DESIGN FOR INDONESIAN EFL BANKING STUDENT Elismawati

IAIN Imam Bonjol, Padang, Indonesia

$129-138$

20. THEGRAMMATICAL CHARACTERISTICS OF TOBA ADJECTIVE

AND VERB AND ITS IMPLICATION IN TEACHING ENGLISH

IN NORTH SUMATERA INDONESIA

Elsina Sihombing

Universitas Negeri Padang, Indonesia

$139-152$ 
21. MEANINGFUL AND BRAIN BASED LITERATURE LEARNING MODEL

AS THE NEEDS OF STUDENTS AND FACULTIES

AT THE FACULTY OF TEACHER TRAINERS

IN MUHAMMADIYAHUNIVERSITY OF BENGKULU

Elyusra and St. Asiyah

FKIP Muhammadiyah, University of Bengkulu, Indonesia.

$153-158$

22. DEVELOPMENT OF ENGLISH TEACHING MATERIALS BASED ON CONTEXTUAL

FOR STUDENTS OF MADRASAH ALIYAH GRADE X

Enidar

Universitas Negeri Padang, Indonesia

$159-168$

23. LANGUAGE LEARNING STRATEGIES;

NETWORKINGAT HOME AND ABROAD WISDOM IN TOBA BATAKCULTURE

Erisa Kurniati

Batanghari University, Jambi, Indonesia

$169-174$

24. FOSTERING STUDENTS' CRITICAL THINKING SKILL

WITH AN INTERNET-BASED NATURE OF GOOGLEDOCS

Erly Wahyuni, Estu Widodo, Hartono, and Sobah Sabilil M.

University of Muhammadiyah Malang, Indonesia

25. THE IMPLEMENTATION OF A STUDENT CENTERED APPROACH

IN TEACHING READING IN ENGLISH IN INDONESIA: A CASE STUDY

Erni and Hamidah Yamat

FKIP Universitas Riau, Indonesia; Faculty of Education UKM, Malaysia

$182-188$

26. LANGUAGE LEARNING STRATEGIES USED BY SUCCESSFUL STUDENTS OF VOCATIONAL SENIOR HIGH SCHOOLS OF RIAU PROVINCE AND RIAU ARCHIPELAGO

PROVINCE-INDONESIA AND THEIR SOCIO-ECONOMIC, ACADEMIC,

AND TYPES OF SCHOOL FACTORS

Fakhri Ras, Mahdum, Hasnah Faizah, and Mohammad Amin Embi

University of Riau, Indonesia

27. MEANS OF REVEAL CHILD'S FEELINGS THROUGH DRAWING IN KINDERGARTEN

Farida Mayar

Universitas Negeri Padang, Indonesia.

$201-205$

28. IMPROVING STUDENTS' ABILITY IN WRITING NARRATIVE BY USING SONG

Fitra Murni AR.

SMA Negeri 3 Padang Panjang, Indonesia.

29. WEB-BASED ON ENGLISH LANGUAGE TEACHING AND LEARNING ENGLISH AT ENGLISH DEPARTMENT OF UNP

Fitrawati

Universitas Negeri Padang, Indonesia

30. USING MODERN TECHNOLOGY IN TEACHING AND LEARNING OF ENGLISH

Fitriadi Lubis

IAIN Padangsidempuan, Indonesia.

$224-232$

31. UNDERSTANDING THE MEANING OF SIGANJUA LALAI

THROUGH WOMEN DANCE MOTIONS IN WEST SUMATRA

Fuji Astuti

Universitas Negeri Padang, Indonesia

233-237 
32. EFFECTIVENESS OF USING TUTORIAL VIDEO AS A MEDIA

IN LEARNING PROCESS OF FINE ARTS AT SENIOR HIGH SCHOOL

Fulkha Tajri M. and Ramalis Hakim

Universitas Negeri Padang, Indonesia

$238-242$

33. STANDARDIZING TEACHING ENGLISH VOWELS

IN EMPOWERING STUDENTS' PRONOUNCIATION TODAY

Hamka

IAIN Padangsidempuan, Indonesia.....

34. REINTRODUCING MINANGKABAU CUSTOM OF FUNERAL CEREMONY

IN INTERCULTURAL CONTEXT BY USING CAMTASIA STUDIO

Hanifah andHayati Syafri

IAIN Bukittinggi, Indonesia

35. INTANGIBLE CULTURAL HERITAGE TRADITIONAL EXPRESSIONS MINANGKABAU: Systems Society Technologies on Point of Educated and Noble Advices

Hasanuddin WS. and Emidar

Universitas Negeri Padang, Indonesia

$265-272$

36. LEXICAL VARIATION OF THE RIAU MALAY LANGUAGE

IN MERANTI ISLANDS; GEOGRAPHICAL DIALECT

Hasnah Faizah A.R. and Juli Yani

Universitas Riau, Indonesia

$273-279$

37. UTILIZING THE MODEL OF SOCIO-CULTURAL AFFECTIVE STRATEGIES

IN ENCOUNTERING INTERCULTURALITY VIA VIDEO CALL

Hayati Syafri

IAIN Bukittinggi, Indonesia

$280-285$

38. PLACEMENT OF THE CURRENT TECHNOLOGY

TO STIMULATE STUDENT CREATIVITY IN DANCE CREATION

AND THE IMPACT ON LEARNING OF CHOREOGRAPHY EFFECTIVENESS

Indrayuda

Universitas Negeri Padang, Indonesia

$286-289$

39. CONSTRUCTING AN ATTRACTIVE "CHAT-ROOM"

TROUGH BENEFICIAL OF WHATSAPP IN IMPROVING STUDENT ENGLISH ABILITY

Iradatul Hasanah and Nadya Felly

Universitas Negeri Padang, Indonesia.

40. DEVELOPING SOLFEGIO INSTRUCTION BY USING DIRECTIVE LEARNING MODEL AT MUSIC DEPARTMENT OF PADANG UNIVERSITY

Jagar Lumbantoruan

Universitas Negeri Padang, Indonesia

41. INTEGRATING READING AND WRITING SKILLS IN ENGLISH TEACHING

AS DEMANDED BY CURRICULUM 2013 AT JUNIOR AND SENIOR HIGH SCHOOLS

Jufri

Universitas Negeri Padang, Indonesia

$302-312$

42. THE SENTENCE SPEECH IN THE LANGUAGE IMPERATIF BY TEENAGER' FACEBOOK Juli Yani and Willy Hendarto Surya

Universitas Lancang Kuning, Riau, Indonesia

313-319 
43. THE UTILIZING INSTRUCTIONAL IN ENHANCING STUDENTS' LISTENING ABILITY THROUGH MOVIE REPORT AT LISTENING III

\section{Luli Sari Yustina}

IAIN Imam Bonjol, Padang, Indonesia

44. TEACHERS' NEED ON AUTHENTIC ASSESSMENT FOR SPEAKING SKILLS

M. Zaim and Refnaldi

Universitas Negeri Padang, Indonesia

45. INFLUENCE OF MOTIVATION AND LANGUAGE LEARNING ENVIRONMENT

ON THE SUCCESSFUL EFL LEARNING

Masyhur

Universitas Riau, Indonesia

$331-348$

46. TRANFORMATION WISANGGENI FIGURE IN NOVEL WISANGGENI SANG BURONAN

BY SENO GUMIRA ADJIDARMA AND COMICS LAHIRNYA BANGBANG WISANGGENI

BY RA. KOSASIH IN THE CONTEXT OF CULTURECONTEMPORARY

Mila Kurnia Sari and Samsiarni

STKIP PGRI West Sumatra, Indonesia

47. SYSTEMIC FUNCTIONAL LINGUISTICS, E-TOOL, REAL LIFE CONDITION, AND THE SENSE OF SCIENCE IN SCIENTIFICSTUDENTS' WRITING:

BRIDGING THE ASPECTS

Muhammad Affandi Arianto

State University of Malang, Indonesia

$355-361$

48. NEGATION IN MINANGKABAUNESE AS SPOKEN IN BONJOL

Muhammad Yusdi

Universitas Andalas, Padang, Indonesia

$362-367$

49. LEXICON OF FOOD IN MINANGKABAU LANGUAGE BASED

ON THE VERB AND THE TYPE OF MATERIALS USED

Nadra, Fajri Usman, and Meksi Rahmanesti

Universitas Andalas, Padang, Indonesia $368-372$

50. ETHNIC DANCE RELATIONSHIP WITH THE CULTURAL OF THE COMMUNITY: A STUDY ETHNOCHOREOLOGY

Nerosti

Universitas Negeri Padang, Indonesia

51. APPLICATION OF COOPERATIVE APPROACH THINK TALK WRITE (TTW) TYPE

IN THE LEARNING FOR WRITING A RESEARCH PROPOSAL

BY UTILIZING THE MENDELEY APPLICATION

TO STUDENTS STKIP PGRI WEST SUMATRA

Ninit Alfianika

STKIP PGRI West Sumatra, Indonesia

$382-388$

52. IDEAL CHARACTERS OF YOUNG FIGURES IN LOCAL-COLOR MINANGKABAU NOVELS AS A SOURCE OF CHARACTER EDUCATION LEARNING MATERIALS

Novia Juita, Nurizzati, and M. Ismail Nasution

Universitas Negeri Padang, Indonesia 
53. "SHARPENING” THE ENGLISH LANGUAGE PROFICIENCY

BY CULTURAL APPROACHES TROUGH LITERAY WORKS AS MEDIUM

Novia Murni

Institut Seni Indonesia, Padang Panjang, Indonesia

$398-403$

54. ASSESSMENT AUTHENTIC MODEL DEVELOPMENT OF SHORT STORY TEXT APPRECIATE SENIOR HIGH SCHOOL STUDENT (SMA) CURRICULUM 2013:

CASE STUDY PERFORMANCE ASSESSMENT CAPABILITY

Nurizzati and Ena Noveria

Universitas Negeri Padang, Indonesia

$404-409$

55. THE USABILITY OF SKYPE IN ELABORATING THE ISSUE OF FEMINISM

FOR STUDENTS' INTERCULTURAL SENSITIVITY

Nursyarifa, Hayati Syafri and Hanifah

IAIN Bukittinggi, Indonesia.

56. VALUE, IDEOLOGY, AND LIVING PRACTICES:

OVERVIEW ON MINANGKABAU PROVERBS

Oktavianus

Universitas Andalas, Padang, Indonesia

57. UTILIZING OF YOUTUBE AS TECHNOLOGY IN WRITING POPULAR ARTICLE

Putri Dian Afrinda

STKIP PGRI Sumatera Barat, Indonesia

$422-427$

58. APPLICATION OF COOPERATIVE APPROACH TALKING STICK TYPE

WITH ASSISTED BY AUDIOVISUAL MEDIA

IN LEARNING TO SPEAK AT THE JUNIOR HIGH SCHOOL

Rahayu Fitri

STKIP PGRI West Sumatera, Indonesia

$428-433$

59. USING READING TEXTS CONTAINS PROBLEMSTO SOLVE TO PROMOTE WRITING

Rahmah Apen

Universitas Negeri Padang, Indonesia.

60. CLASSROOM INTERACTIONS IN ENGLISH LANGUAGE TEACHING

Ratmanida

Universitas Negeri Padang, Indonesia

$349-445$

61. ADVANCES IN TECHNOLOGY: LANGUAGE INPUTS AND TEACHING

AND LEARNING SOURCES

Rusdi

Universitas Negeri Padang, Indonesia

$446-450$

62. PROBLEMS MADE THE SMP TEACHERS

IN DEVELOPING THE STEPS OF THE LESSON PLANS (RPP'S)

IN INTRODUCING THE TEACHING MATERIALS

Saunir Saun

Univesitas Negeri Padang, Indonesia

$451-457$

63. ACHEH'S AUTONOMY AND LOCAL PARTY NAMES VERSUS PAPUA'S ONE

UNDER INDONESIAN CONSTITUTIONS:

A STUDY OF INTERTEXT AND "INTERCONTEXT

Sawirman

Universitas Andalas, Padang, Indonesia

$458-463$ 
64. SENGGAKAN OF CALUNG PERFORMANCE AS AN ART EXPRESSION

AND REFLECTION OF CHARACTER OF BANYUMAS SOCIETY

Suharto

Semarang State University, Indonesia

$464-470$

65. STUDENTS' PERCEPTION ON TEACHER'S USE OF TECHNOLOGY

IN TEACHING ENGLISH

Suswati Hendriani and Yasti Januariza

IAIN Batusangkar, Indonesia

66. APPROACH OF WESTERN MUSIC THEORY

ON NUSANTARA MUSIC OF LEARNING IN SENDRATASIK DEPARTMENT

PADANG STATE UNIVERSITY

Syahrel

Universitas Negeri Padang, Indonesia

67. TECHNOLOGY IN UNDERSTANDING POETRY

BY ENGLISH DEPARTMENT STUDENTS OF FKIP UNIVERSITAS RIAU

Syofia Delfi

Universitas Riau, Indonesia

$479-483$

68. THE IMPLEMENTATION OF TRADITIONAL GAME

FOR KINDERGARTEN STUDENT'S CHARACTER BUILDING

Tati Nurkhikmah and Nurul Fatatik

State University of Semarang, Indonesia

$484-490$

69. THE EFFECTIVE USES OF INFORMATION TECHNOLOGY

IN TEACHING RUSSIAN LANGUAGE AND LITERATURE

Thera Widyastuti

Universitas Indonesia

$491-496$

70. THE UTILIZATION OF FOLKTALES AS THE MEDIA TO CULTIVATE CULTURAL

AND NATIONALCHARACTER EDUCATION

Titek Suyatmi

Universitas Ahmad Dahlan, Yogyakarta, Indonesia

$497-501$

71. THE IMPLEMENTATION OF QUEST PROGRAM APPLICATION

IN THE ASSESSMENT OF LANGUAGE LEARNING OUTCOME

Triwati Rahayu, Umi Rokhyati, and Pujiati Suyata

Universitas Ahmad Dahlan, Yogyakarta, Indonesia

72. DYNAMIC INTERCHANGE IN MUSICAL PRACTICE:

SUGGESTING DYNAMIC INTERCHANGE AS EPISTEMOLOGY

AND ITS USE IN TEACHING AND LEARNING MUSIC IN INSTITUTIONS

Tulus Handra Kadir

Universitas Negeri Padang, Indonesia

73. THE APPLICATION OF STAD (STUDENT TEAMS ACHIEVEMENT DIVISION)MODEL BASED ON STRUCTURED CONTRACTUAL TASK IN SPELLING LEARNING OF MINOR IN INDONESIAN COURSE OF UNIVERSITAS NEGERI PADANG, 2016

Utami Dewi Pramesti

Universitas Negeri Padang, Indonesia 
74. ATTRACTING STUDENTS' ATTENTION TO LEARN ENGLISH

BY USING MOTION PICTURE SLIDE SHOW

Wahyuni Restu Amalia and Suswati Hendriani

IAIN Batusangkar, Indonesia .....

75. CHARACTER DEVELOPMENT THROUGH THE WORK OF ARTS

Yahya

Universitas Negeri Padang, Indonesia

76. THE MAGIC OF TEACHING: HOW MEDIA CHANGES CLASSROOM ATMOSPHERE IN SPEAKING CLASS

Yanti Ismiyati

Batanghari University, Jambi, Indonesia

77. HAMKA'S CONCEPTION TOWARD MINANGKABAU CULTURE:

A Literature Sociology Studies of Hamka's Novels

Yasnur Asri and Zulfadhli

Universitas Negeri Padang, Indonesia.

78. DEVELOPMENT OF LEARNING DEVICE OF DECORATIVE FASHION DESIGN

ASSISTED BY CORELDRAW PROGRAM TO IMPROVE

CREATIVITY OF FASHION DESIGN COLLEGE STUDENT

Yenni Idrus

Universitas Negeri Padang, Indonesia

$544-548$

79. THE EFFECT OF COOPERATIVE LEARNING MODEL

TYPE STUDENT TEAM ACHIEVEMENT DIVISIONS (STAD)

ON READING COMPREHENSION ABILITY OF JBSI STUDENT

OF INDONESIAN LANGUAGE EDUCATION PROGRAM

FACULTY OF LANGUAGE AND ARTS OF UNIVERSITAS NEGERI PADANG

Yulianti Rasyid

Universitas Negeri Padang, Indonesia

$549-555$

80. DESIGNING MEDIA FOR EFL LEARNERS

BY UTILIZING AUTORUN PRO ENTERPRISE II SOFTWARE

Yummi Meirafoni, Melviola Fitri, and Putri Yulia Sari

Universitas Negeri Padang, Indonesia

$556-562$

81. INTEGRATIVE REVOLUTION OF LEARNING METHOD

TOWARD LANGUAGES SKILLS

Yunnisa Oktavia

Universitas Putera Batam, Indonesia

$563-566$

82. THE POSITION OF TEACHER CAN NOT BE REPLACED BY INSTRUCTIONAL MEDIA

Yos Sudarman

Universitas Negeri Padang, Indonesia

83. INCREASING STUDENTS' MOTIVATION AND ENTHUSIASM

TO LEARN ENGLISH BY USING VIDEO

Zulvi Asny and Suswati Hendriani

IAIN Batusangkar, Indonesia .

$575-580$ 
The Papers Published in The Proceeding Have not been Edited Yet 


\title{
LOCAL WISDOM CONTENT IN MODERN SHORT STORIES WRITTEN BY MINANGKABAU AUTHORS
}

\author{
Agustina and Yasnur Asri \\ Universitas Negeri Padang \\ tien_agustina08@yahoo.com
}

\begin{abstract}
Minangkabau is one of the hundreds of cultures that exist in Indonesia. As a community, ethnic Minangkabau have moral teachings, values and societal norms. Those values, ethnics, and behaviors regarded as a source of policy in a community's life is called as local wisdom. Literature work is a product of wisdom that is able to provide enlightenment for those who appreciate it. Literature can be defined as manifestation of one's cultural expression and reflection. Thus, literature may enrich the life of the readers through reading, writing, listening and discussing it. It may directly or indirectly enrich life of the readers through experience enlightenment and problems issued in one work of literature as well as its solution. In this study, the Minangkabau local wisdom content can be one of guidance in life. This study is pursuant to the theory of literature sociology which regards literature as manifestation of cultural experience as well as reflection of social-cultural reality. Based on the study, it is found that the content related to the local wisdom in modern short stories written by Minangkabau authors discusses five particular local wisdom. The first one related to life philosophy of Minangkabaunese; standing for what is right and enemies will never be challenged, yet they will not be avoided when they come. The second one is local wisdom based on Minangkabaunese's social life like giving advice, teachings, helping others, saving the earnings, taking a lesson from others' experiences, and preserving the natural sacred surroundings. The third one is local wisdom related to local ceremony or traditional ceremony. This ceremony will be a forum for the local people to train their diplomatic skills and local cooperation. The forth is local wisdom belonging to local principles, norms, and regulations which are actuated in social system. These can be reflected to in Minangkabaunese behaviours who are always becoming hard worker, never be proud of their belongings and ability, making advantage of their natural surroundings, sharing intramarriage system and respecting women. The fifth is local wisdom which is based on tradition, daily basis social attitude, namely; ways of living in a community, waiting for children with traditional foods, provide assistance for construction of public facilities, helping others and returning home when Ramadhan month is coming.

Keywords: Content; Local Wisdom; Modern Short Stories; Minangkabau's Authors
\end{abstract}

\section{A. INTRODUCTION}

This article is based on the research results entitled "Local Wisdom in Modern Short Stories by Minangkabau's Authors", which is motivated by the following four points:

First, Minangkabau culture is one of the hundreds of cultures that exist in Indonesia. As a community, ethnic Minangkabau have moral teachings, values and societal norms, as adopted by the other eastern (Djamaris, 2002: 248) that are implemented by people in everyday behavior with attitudes like respect for others, suave, humble, trustees, and resent temper, haughty and arrogant. Ethical values and behaviors so in this study serve as a source of policy called the local wisdom.

Second, there are at least three important things in literature. (1) The literary work is a reflection of life and society as well as background cultural products. Therefore, literature plays an important role in human life; because in literature there are possibilities that can be used as an alternative in addressing the issue of human life and culture, such as issues of marriage, education, inheritance, loyalty, betrayal, heroism, sadness, excitement, deception, corruptor, harshness, arbitrariness, rape rights, and others presented a writer through his work. (2) The literary work is a means to convey the vision, mission, 
ideology, and the opinion of the author of something seen, felt, observed, and thought about man with all the humanitarian problems in the socio-cultural aspects. Therefore, literature always presents a picture of life (Damono, 2012: 1), including local wisdom content reflecting the culture of the communities. (3) The literary work as an imaginative creative work displays various life phenomena of the events happening in the community as a reflection of real life, at the same time the story materials was taken through the process of seeing, hearing, reading, and even self experience; then processed, flavored, and polished with a variety of imagination, forming a creative work as the new world or the world of symbols (words/language). To understand it, is necessary to interpret analysis of ideology carefully contained therein. This is called in the literary work "from words to ideology" because it is reflecting ideology as the fact of communities culture (Hoggart, 1975) so that it is the pronunciation of the cultural experience as a culture expression.

Third, studying reflection of local wisdom content in modern short stories by Minangkabau author is narration reading from past efforts undertaken at the present time, meanwhile the narration reading at the present time towards the future time. It is because mainly in the reform era, one of the phenomena is still found that there are many prevalent acts of long-standing degradation of human dignity, but has not been seriously solved. As presented by Krishna (2005: 24) that reading past narration done at the present time is like doing the colonial narration reading at the postcolonial period; and this is important to do it because the possibility of the past narration had been considered usual narrative in fact to contain a mapping history of colonial rule in it. Krisna's view is based on the opinions of Aschroft (1983: 3) that colonialism is an active, alive, and sustainable system in a variety of institutional and discursive practices of a particular society. Thus, the possibility of traces of colonialism is still alive in Indonesian novels, but not least the novels created by Minangkabau's ethnic author.

Fourth, literary work is a wisdom product that is able to provide enlightenment for those who appreciate so that getting inner experience from it. Human being seen from psychological point of view, has tendency to love stories because the literary work can enrich the lives of the lovers either through reading, writing, listening or discussing them. Thus, either directly or indirectly, literary work enriching the lives of its readers through the experience enlightenment and the problems occurred as well as the problem solutions.

Fifth, there are many value elements that can be explored and then being used as a model of the literary works. It can be also used as an important asset in building the character of the nation children. To achieve this, the contribution of literary works in building Indonesian people is very significant for the character building starting from the individual initial development by giving readings which is able to instill the values of kindness. In line to this study, the local wisdom content of Minangkabau can be used as guidelines in life.

Based on the five reasons mentioned above, the study of the local wisdom content in modern short stories written by Minangkabau authors is important to focus on the problems of "What are the forms of local wisdom content reflected in the modern short story of Minangkabau authors?" This assessment using a combination of theoretical text interpretation and literature sociology is to interpret and make sense specifically about the local wisdom content in modern short stories by Minangkabau author. Referring to theory Ricoerr (in Kleden 1997: 42) the text (in the modern short story works by Minangkabau author) can be used as a paradigm to understand and explain the actions and human experience; the interpretation of the text aiming is not merely to understand the meaning of the text itself, but rather to understand human existence and the world contained therein.

\section{B. RESEARCH METHODS}

This research method is a qualitative descriptive. Data of this study are word, sentence, and discourse that include local wisdom in modern short stories written by Minangkabau authors, meanwhile the object of this study is the modern short stories published by Kompas Newspaper. Selection of the object of study conducted purposively by considering (1) the focus of research of the local wisdom content on the short story, (2) the levels of the literary value of short stories, (3) popularity of the authors, (4) the viability of short stories and is always in demand by readers, and (5) the effect of short stories on Indonesian society. 
The data collection is performed by using a read-note, in line with data analysis simultaneously in order to be validated by triangulation with the data sources (Moleong, 2002: 104). The research instrument is the researcher herself assisted by a table of data inventory. Data analysis techniques performed by the content analysis method and the method of reading heuristic and hermeneutic, with the aim to explore the content, messages contained on the object of research, and give meaning to the message to describe social phenomena occurred as expressed by Endraswara (2011: 160) that the analytical techniques to understand the literary works covering extrinsic elements such as moral message, educational, philosophical, religious values, and others. Data are analyzed with the following steps. (1) Reading, inventory, and identifying the motives of the story which is possibly abstracted as local wisdom content explicitly or implicitly contained in the short story. (2) Interpreting and making a creative interpretation of local wisdom content which is found in short stories. (3) Summarize all interpretation results to obtain the picture of the local wisdom content conveyed by the author through the short story. (4) Linking forms of local wisdom in the short story (fictional reality) with the public opinion (objective reality) to the events of the local wisdom content in the short story. (5) Develop a research report.

\section{RESEARCH METHODS}

Based on data analysis, it is found five forms of local wisdom in modern short stories by Minangkabau authors, namely basing on: (1) views of life (philosophy), (2) the attitudes of social life, advice, and endeavor, ( 3 ) ceremony or traditional ceremonies, (4) principles, norms and rules and regulations being shaped into social systems, and (d) daily habit or behavior in social interaction.

\section{Wisdom Based on View of Life (Philosophy)}

Local wisdom is based on a view of life (philosophy) reflected in the modern short story by Minangkabau author is (1) bravery appeared because of the truth (standing for what is right) and (2) and enemies will never be challenged, yet they will not be avoided when they come.

a. Bravery appeared because of the truth

Local wisdom being bravery appeared because of the truth is revealed in the Fourth Paragraph of the short story written by Joni Syahputra, the figure of Johan making resistance movement when arbitrary treatment made by his uncles as Johan thought it is not in accordance with the guidance of traditional Minangkabau. They will mortgage the inherited wealth only to finance a campaign for being a legislative candidate, one of the members who has returned home after failing in the wandering about the country. Yet according to Tambo, the inherited wealth may be mortgaged or sold in case of three things: (1) the corpse lying in the middle of the house, meanwhile there is no money to organize the funeral; (2) the niece has to be married and already has a mate, meanwhile having no money for marriage wedding; (3) the leak longhouse (Rumah Gadang) meaning heritage house has rotted, while the clan community having no money to fix it. However, Datuk Birahin as the headman of Caniago tribe (suku caniago) adds one more paragraph, namely (4) membangkik batang tarandam (raising the immersed rod) according to them, just in case Syahbuddin as the failed (perantau) gets success to be a house representatives member, then all degrees of Tribe Caniago (suku caniago) family will arise again or be respected. However, Johan, who is a former activist at the university does not want to follow the reason for adding one more paragraph in the legend because Johan believes to sell the inherited wealth for the capital of legislative candidate campaigns is not an action justified by the Minangkabau customs; moreover, the inherited land to be sold is belonging to his mother.

Sebelum dinding diruntuhkan, Johan menepati janjinya sebagai lelaki Minang sejati. "Langkahi dulu mayat saya." Ia membabi buta sore itu. Keris pusaka satu-satunya peninggalan ayahnya tercabut dari gagangnya. Darah memercak ke atas bumi. Lima orang datuk suku Caniago tergolek bersimbah darah. Johan kini ditahan di kantor polsek.

Is it wrong that the resistance movement made by Johan?. In accordance with Minangkabau custom, nephew must follow instructions from uncle as long as the uncle still holds to the truth, it is because the Minangkabau people build a reference in the structure by combining hierarchical institution with reference values of decency and truth as reflected in legislation or advice, namely kamanakan barajo ka mamak, mamak barajo ka pangulu, pangulu barajo ka alua jo patuik, alua jo 
patuik barajo ka nan bana, nan bana badiri sendirinyo. Conversely if uncle (mamak) acts arbitrarily, then the advice applies to Raja alim raja disembah, raja lalim raja disanggah means nephew is obliged to rectify (mamak) the uncle's mistakes. Johan enforces the local wisdom 'bravery because of the truth' (standing for what is right), even though to the leader of his tribe.

b. Enemies will never be challenged, yet they will not be avoided when they come

The local wisdom is based on way of life that is 'enemies will never be challenged, yet they will not be avoided when they come' being reflected in the short story Pakiah Pariangan written by Gus TF Sakai. A thug commits extortion against two teenagers who were begging and getting resistance from the Pakiah

Dan, kejadian yang sebenarnya itu sangat sederhana. Seorang preman tukang palak, dengan lebih dulu menggertak, merogoh buntal salah seorang pengemis remaja. Tetapi, begitu tangan si preman masuk ke buntal, mulut si preman segera terpekik. Di dalam buntal itu, entah bagaimana caranya, tangan si preman telah dikunci oleh tangan si pengemis remaja. Si preman tukang palak itu melolong-lolong, tubuhnya tertekuk-tekuk, sampai terbungkuk-bungkuk, memohon-mohon meminta ampun agar tangannya dilepaskansed.

Pakiah is the result of Surau (small prayer house in the village) education that has been applied in Minangkabau. Boys before marriage have to sleep in the Surau, where they gain knowledge about life skills, bersilat (traditional self-defense arts), speech, trade and cultivate land. So, surau is not only a place of prayer and religious study, but also as a place to sharpen the intelligence of the brain, heart and physical as well as a place of learning Silek (traditional self-defense arts) originating from the Minangkabau. Surau education is the basis for the growth of the local wisdom courage to defend themselves and establish the truth as well as a preparation for the Minangkabau youth to wander.

\section{Local Wisdom Based on Social Life, Giving Advice, and Moral Lesson}

a. Life shall be mutual help

Local Wisdom Based on Social Life shall be mutual help. This is reflected in the short story of Ngiang Kata Ibu karya Yusrizal KW. Figure Aku ( I) always give alms to every beggar who comes to his house. This habit was transmitted by his mother since he was a child, simple living, and care for others.

Mengenang ibu, aku merasa mengenang dirinya dalam mandi cahaya kemuliaan. Ketika dia telah tiada aku baru menyadari, ia betul-betul menjalani hidup ini dengan sederhana. Ibu selalu kulihat seperti dalam senyum. Selalu mengajarkanku agar menjauhi pertengkaran karena berebut uang, jangan memakan uang atau hak orang lain, apalagi korupsi. Kata ibu, masih kuingat, jangan biarkan fakir miskin, para duafa tak membawa apa-apa, dari tangan mereka yang bertadah ada sabun pembersih rezeki kita dari ketakhalalan yang tak sengaja.

b. Life shall be economized or earning shaving

Short Story of Peti Ayah dan Tiga Puluh Tahun Setelah Itu written by Farizal Sikumbang. It reflects local wisdom on liking for saving for future. Supplies storage for Minangkabau people is called Rangkiang located next to the longhouse, while the storage of the inherited wealth such as gold deposited in the box. Minangkabau people regard gold not only as jewelry, but it also functions as a deposit for backup when needed some day, and if not used, it will be the legacies.

"Kau ingat tiga puluh satu tahun yang lalu? Saat kau dan ayah menemukan sebuah peti sebesar kardus mi instan di belakang rumah? Lalu, untuk apa Uda tanyakan tentang peti itu? Jangan berlagak tak tahu. Tentu peti itu banyak emasnya kan? Emas?, Ya, bukankah orang tua-dulu suka menyimpan emasnya dalam peti?" 
c. Provide assistance for construction of public facilities

In the short story of Sumenda Damhuri Muhammad expressed the nature of communal Minangkabau society among others is a joint ownership. This concept is applied in the activities of public facilities by involving all levels of society in accordance with their respective capabilities.

Orang-orang kampung kami tak henti-henti membangun surau. Tiada pernah lelah mereka menghimpun wakaf, zakat, infak, sedekah. Menggalang dana untuk mendirikan surau. Setiap musim lebaran, mereka mengetuk hati para perantau yang pulang ke kampung untuk bersenang hati ikut menyumbang. Ada yang memberikan derma dalam bentuk bahan bangunan, ada pula yang menyumbang uang tunai....

Local wisdom helping homeland as expressed in Cerpen (in short stories) of Kakak Dari Rantau written by Yusrizal KW. Returning the figure of Suar to his homeland is to pay a religious visit to his mother's grave as such for along time he has been living in rantau (other people home town), besides, he also takes time to come to Surau to show his concern for the homeland, even though he himself seldom performs religious service in the Surau.

"Tadi, di surau, disebutkan pakai pengeras suara, ada infak 1 juta rupiah untuk pembangunan surau dari Om Suar. Wah, Aisyah jadi bangga dalam hati, karena disebutkan begini: infak satu juta rupiah dari Suar, kakaknya si Narti yang merantau ke Jakarta!”

d. Mutual help among others of the same home village

In the short story (Cerpen) Diri Juga Ingin Pulang written by Zalfeni Wimra telling the figure of Diri, a friend of Awis, who has helped and always asked Awis for savings, is now asking Awis for giving him a job.

"Wis, beri aku pekerjaan," Diri memohon. Awis ternganga, tak tahu jawaban apa yang mesti diucapkannya pada Diri. Permintaan Diri terasa aneh dan kurang tepat dibicarakan dalam suasana seperti itu. Bukan hanya karena teringat pada jasa-jasa Diri yang besar kepadanya.

In the short story of Inyiak Agus written by Abdulkadir Linin telling that Inyiak Agus, an old man is as Garin Surau (a man in charge of taking care of surau). In the past when he was living in perantauan (other people home area), he has provided much assistance to the young perantauperantau from Minangkabau, among of them, there is Datuk Engku.

Rupanya, Engku Datuk itulah yang sering mengirimi Inyiak Agus uang. Kata Engku Datuk, Inyiak Agus banyak sekali jasanya pada orang-orang yang merantau ke Tanjungkarang. Termasuk Engku Datuk. Pertama beliau sampai di Tanjungkarang, Inyiak Aguslah yang menampung. Inyiak Agus juga yang mengajarinya berjualan kelontong keliling kampung. Waktu itu beliaukan masih kecil. Belum diangkat jadi Datuk," terang istriku. (Inyiak Agus).

Diri's attitude was giving much help to Awis when moved to Pekanbaru, at the mean time Inyiak Agus rendering great service to the people who came to his settled urban area is a local wisdom of Minangkabau people which had been previously established among each other during living in the other people home town.

e. Taking a moral lesson from the events experienced by other people

Local wisdom is reflected that taking moral lessons from the experience of others are found in the short story (Cerpen) of Abdul Kadir Linin that tells a husband whose name is Masri failed making an affair with Farni after getting information on a male teacher is caught red handed due to having an affair with a female teacher, and thereafter they have been thrown out from the village. This is consistent with the beliefs of the Minangkabau people "mengambil contoh pada yang sudah, mengambil tuah pada yang menang " (taking an experience which has already occurred, picking up a good luck for the truth"). 
"Ya! Kasihan kan? Bunda pikir begini; apa yang akan dikatakan Pak Guru pada anakanaknya yang beranjak remaja? Pada istrinya? Betapa malunya dia! Pada masyarakat yang menyeganinya selama ini. Apalagi pada orang-orang yang pernah diberinya nasehat, diberinya wejangan! Bu Fet juga; apa yang akan dia katakan jika suaminya pulang dari Ujungpandang? Repot sekali, kan? Coba Ayah bayangkan! Barangkali itulah sebab nabi bilang; daripada menyentuh perempuan yang bukan muhrim lebih baik menyentuh bara api...."

f. Environmental preservation sacred

In short story (cerpen) of Kaki yang Terhormat written by Gus TF Sakai is reflected that Harun who has been wealthy in the town, going to everywhere by helicopter is finally returning home with a big plan for construction of a cement factory, on the contrary he ignores environmental preservation which is being sacred so far.

Meskipun sudah banyak orang-orang suruhan Harun datang dan sudah bekerja memperlebar dan mengaspal jalan ke bukit kaki, Harun belum juga pulang ke kampungnya. Pihak keluarga mulai gelisah dan bertanya-tanya kenapa Harun belum juga pulang. Sampai akhirnya sebuah berita besar menghantam, Harun terlibat kasus korupsi....

"Kau tahu apa sebenarnya yang membuat Mak Etekmu celaka?" Saya menarik kepala. Memandang bibir krumput nenek lalu menggeleng. "Karena ia tak lagi menggunakan kakinya. Karena ke mana-mana hanya dengan kendaraan, di atas helikopter itu saja."

Considering a hill sacred is a local wisdom found in a society in the frame of taking care of the nature preservation, due to Harun's attitude being to clear-cutting a foot hill, this is as the form of refusing a wisdom of the certain society group. The picture of disaster happened to Harun is moral lesson which should be accepted, believed, and appreciated by the community.

\section{Local Wisdom Based on Customs and Traditions Ceremony (Upacara Adat)}

a. Customs and traditions ceremony is forum to train diplomatic skills

Local wisdom is reflected in short story (cerpen) of Minangkabau author, Uang Jemputan written by Farizal Sikumbang, seeing the ceremony that is the customs and traditions ceremony as a forum to train diplomatic skills.

"Setelah sepakat akan menikah, keluarga aku dan Faraswati mengadakan pertemuan dalam rangka merundingkan pernikahan mereka. pertemuan ini dalam rangka proses negosiasi membahas berbagai hal yang berkaitan dengan pernikahan antara kedua anak mereka. Menurut adat Minangkabu proses pernikahan harus dilakukan dengan mengikuti ketentuan adat, diantaranya proses pinang-meminang. yang berbeda-beda....

In the process of peminangan (making a proposal of marriage pre-negotiation) to use pasambahan which is a test event expertise in using words full of allusions, sayings, and proverbs to express their opinions in the negotiations, all at once used to train the sharpness of intuition and interpretation capabilities, which for the Minangkabau people as part of the height of the intelligence. The expertise of expression in the negotiations through pasambahan is the local wisdom of Minangkabau. That is the reason, many Minangkabau leaders during Indonesian's independence movement tend to appear as negotiators with the Netherlands or other parties due to their trained diplomatic communication skills and negotiation in community.

b. Customs and traditions ceremony fosters principles of mutual cooperation

Customs and tradition ceremony also fosters attitudes of mutual cooperation is reflected in the short story (cerpen) of Dendang Membara Pirin Bana written by Raudal Tanjung Banua. 
"Setelah bertahun-tahun merantau, Kudal pulang ke kampung. Kepulangan Kudal sekaligus untuk melakukan helat khitan anaknya. Kudal ingin mengundang seorang perebab ke rumahnya. Bagi Kudal, mendengarkan rabab setelah lama di rantau sekaligus akan mengobati kerinduannya pada masa di kampung dulu sebelum merantau". "Setelah bertahuntahun merantau, Kudal pulang ke kampung. Kepulangan Kudal sekaligus untuk melakukan helat khitan anaknya. Kudal ingin mengundang seorang perebab ke rumahnya. Bagi Kudal, mendengarkan rabab setelah lama di rantau sekaligus akan mengobati kerinduannya pada masa di kampung dulu sebelum merantau”.

It is also found in short story (cerpen) of Baralek Gadang written by Indrian Koto applying the proverb of kaba baik bahimbauan, kaba buruak bahamburan bahimbauan. If any good news will be informed to other people in order they come to help as well as for hospitality of friendship.

Masyarakat kampung Lansano datang membantu, ada yang membantu mengaduk nasi lamak pulut hitam, menghiasi kamar pengantin, memasang kelambu, mengatur kasur, dan sprei. Ibuibu sibuk mengaduk gulai, memeras santan, menata piring, mencincang cubadak, mencabik daging, membuang sisik ikan, memasak nasi dan air. Malam itu perkampungan kecil yang bernama Lansano itu akan ramai oleh kesibukan-kesibukan kecil, mengingat kedua mempelai berasal dari desa yang sama. Sehingga anak muda di kampung sibuk siang dan malam membantu pembikinan panggung dan perlengkapan-perlengkapan kecil di rumah kedua mempelai.

The two short stories above reflect the typical nature of Minangkabau society on joint ownership (communal bezit). Each individual becomes the common property of the group, on the contrary, each group of $s u k u$ (tribe) becomes the property of all individuals who are members of the group. A sense of belonging is a source of local wisdom in solidarity (solidaritas), togetherness and a sense of mutual help. The concept of living together contained in principle of Sapikua Sajinjiang which means mutual assistance as well as mutual help. This principle is the same as the proverb "berat sama dipikul ringan sama dijinjing" which means mutual cooperation.

\section{Local Wisdom is Based on Principles, Norms, and Regulations which are Actuated in Social System}

a. Making the effort to be the person who always works hard

In the short story (cerpen) of Inyiak Agus written by Abdul Kadir Linin telling about the local wisdom based on principles, norms, and rules and regulations which are actuated into a social system that is making effort to be the one who always works. Due to the monetary crisis being having impact on the country, there are a lot of unemployment occurred. However, Inyiak Agus further states that we must be people who keep working in line with the principles of life of Minangkabau society Kok duduak marawiek ranjau, tagak maninjau jarak. Nak kayo kuek mancari, nak pandai kuek baraja.

"Ya. Kalau kita bekerja tetap, terus kehilangan kerja, ya memang susah, he he.... Tapi, kalau tidak bisa jadi orang bekerja tetap cobalah jadi orang tetap bekerja, he he he ...." Aku tercengang dan mulai merasa: Inyiak Agus tidaklah sesederhana yang kuduga.

b. Life shall not be proud of oneself

In going through period of life, the figure in the short story (cerpen) of Pakiah of Pariangan written by Gus TF Sakai, being asked not to be proud of oneself. Inyiak Pakiah Babanso is a martial arts warrior without competition, no one wants to look for trouble with him. He masters Silek tuo and sitaralak, there are two highly efficient silat associations. There is no a lot of movement, but is deadly opponent. He is also undefeated in gelek kobek (tie), tangkok (catching), and kunci (locking joints and hinges) which are the basic capabilities for reflex movements in silat. However, Inyiak is never proud of himself. 
Tetapi, entah bagaimana kemudian, orang-orang mendengar Inyiak Pakiah Babanso menghilang dari dunia silat. Samar-samar orang kemudian tahu, ia kecewa pada Orde Baru yang menjelmakan silek jadi tarian. Bukan soal tariannya, tetapi kepada sesuatu yang sengaja dipertunjukkan. Jadi, bila sekarang Inyiak Pakiah Babanso kembali muncul dan mendirikan pesantren di kampung tua Pariangan, itu sangat masuk akal. Otonomi daerah yang mengembalikan pemerintahan — tak terkecuali pendidikan—ke lembaga-lembaga lokal, telah menjadikan pesantren sebagai pilihan.

c. Utilization of environment for the benefit of life

In the short story of (cerpen) Peti Ayah dan Tiga Puluh Setelah itu, telling the land utilization for cultivation. A desire of father for cultivation is the form of the local wisdom in preparation for the future time because pisang batu (one kind of banana) is a food source that could be used for temporarily substitution of the main food such as rice. Principle of utilization by Minangkabau people is quite high, all lands are utilized in line with the form, location and type, referring to the proverb:

"Nan lurah tanami bambu, nan lereang tanami tabu, nan padek ka parumahan, nan gurun buek ka parak, nan bancah dibuek sawah, nan munggu ka pakuburan, nan gauang ka tabek ikan, nan padang ka paimpauan, nan lambah kubangan kabau, nan rawang payo ka paranangan itiak".

d. Somebody's disgrace is disgrace of all together in $s u k u$ (tribes)

The short story of (cerpen) Orang-orang Larenjang written by Damhuri Muhammad Larenjang reflecting the local wisdom of disgrace can be undivided, someone's disgrace means disgrace of all together in the tribe. Julfahri who insists on marrying Nurhusni is to bring a disgrace on the village people of Larenjang for violating custom restrictions, namely the prohibition of getting married with the same tribe. Their actions are not only embarrassing themselves, but also effecting to the Bendara Gemuk as a tribal leader of which he is eventually excommunicated from the association among the tribes. It is therefore he must bear social sanctions.

Maka, bagi Bendara Gemuk, daripada hidup berkalang malu, tentulah lebih baik mati berkalang tanah. Ia bertahan di rimba Cempuya, menggelepak di dangau lapuk dengan bekal seadanya. Meski lengang dan hawa dingin menusuk-nusuk tulang tuanya, tetap saja terasa lebih baik ketimbang terus-menerus mendengar desas-desus yang tak kunjung reda.

e. Woman being honored as for continuation of descendant and being heir to inherited wealth

Matrilineal system adopted by the Minangkabau society is a form of concern to the woman by giving her privileges, so that the longhouse belonging to woman. Local wisdom is intended to safeguard the security and prosperities of the country of which one of the roles of the woman is taking care of her children as well as her brother. According to the tradition of Minangkabau, one of both husband and wife will experience kok elok tempat berbaur, kok buruk tempat bercerai. It means if both the husband and wife are in harmonies with each other, certainly they will continue to live with, but if any dispute arose, they would be divorced (separated) in life (still any chance of getting married again) and separated because of the death (passing away).

In the short story (cerpen) of Peti Ayah Dan Tiga Puluh Tahun Setelah Itu written by Farizal Sikumbang telling the figure of $A k u$ (I) greatly regret the death of his sister because in accordance with the custom and tradition of Minangkabau, the sister as a heir to the inherited wealth is not only taking care of her children as for the continuation of descent, but also keeping her brother whenever he is being left by his wife and his children. The man in Minangkabau like "abu di ateh tunggua" (ash on the furnace) can come out of his wife's house with one reason or another.

Aku pun menyesali kematian kakak perempuanku itu. Sebab, dalam adat kami, harta pusaka sebenarnya dicurahkan buat yang perempuan. Dan ayah mewarisi kami sawah dan ladang yang berjumlah sepuluh petak. Tapi, bukan, bukan sawah ayah sebenarnya. Sawah itu milik ibu yang diperolehnya dari pembagian harta dari pihak nenek. Ayah hanya menggarapnya karena tak punya pekerjaan lain. 
Furthermore, in the short story (cerpen) of Rumah Untuk Kemenakan written by Iyut Fitra stating as far as any of the children and grandchildren of the Minangkabau people go wandering, as long as they still have the inherited wealth (high), they and their descendants will still have a hometown as well as they are still proud of the Minangkabau.

"Rumah tersebut memang milik ibumu. Ibumu yang membangunnya dulu. Tapi rumah itu didirikan di atas tanah pusaka, tanah milik kaum kita. Dan satu hal lagi yang perlu kamu ketahui, kemenakanmu banyak yang perempuan. Mereka lebih punya hak untuk menempati rumah itu. Ini sudah kewajiban Mamak untuk mengatakannya....

Berdasarkan kearifan lokal Minangkabau tersebut, wanita sebagai seorang Bundo Kanduang dituntut untuk menjadi seorang yang taat beragama, cerdas, berbudi pekerti, bijaksana, dan sifat-sifat terpuji lainnya Based on the local wisdom of Minangkabau, the woman as the Bundo Kanduang (respectful term for honored mother) being claimed to be a devout, intelligent, well-mannered, thoughtful, and other excellent properties. Therefore, women should understand the phrase "tahu di mudharat jo manfaat, mangana labo jo rugi, mangatahui sumbang jo salah, tahu di unak kamanyangkuik, tahu di rantiang ka mancucuak, ingek di dahan ka mahimpok, tahu di angin nan basiruik, arih di ombak nan basabuang, tahu di alamat kato sampai". The phrase reminds woman in Minangkabau in order to always remember that she as the Bundo Kanduang (owner of tribe) should be a full model to maintain the wisdom as well as the good name of either the family or tribe.

f. Inherited wealth bequeathed to woman, if it is to be mortgaged,

should be discussed with the mother's brother.

In Minangkabau, harta pusaka tinggi (high inherited wealth) mortgaged by the ancestor to her daughter and intended for the benefit of her people. Besides, it is also known as harta suarang (low/not inherited wealth), it means that the whole property (common property) jointly acquired by husband and wife during their marriage, can be mortgaged by the husband to his wife and children. According to the Minangkabau traditions, women in the high heritage is merely mastering and maintaining the heritage because it can be functioned if it has met the requirements specified by the custom and tradition. It is the reason a man related by the marriage is not entitled to sell his wife's inheritance. Customary rules require that if woman sells inheritance shall be either under permission or approval of mother's brother (mamak). This is a form of local wisdom of the Minangkabau tradition in the frame of authority delegation to the brother in order to control his sister.

The situation mentioned above is reflected in the short story (cerpen) of Semenda written by Joni Syahputra. Johan gets angry with his sister for selling two pieces of land of rice field mortgaged by their parents, is used for buying a new motor cycle for his brother in law without under discussion with him previously.

"Jelas itu sangat bertentangan dengan adat kita. Kamu sebagai satu-satunya anak lelaki seharusnya diberi tahu. Memang menurut adat Minang sawah serta harta pusaka lainnya jatuh ke tangan perempuan, tetapi sebagai 'mamak' di dalam keluarga, kamu wajib dibawa bermusyawarah. Kalau saya lihat, sekarang semendamu itu sudah ingin menguasai semua harta pusakamu. Ini tidak bisa dibiarkan terus. Sebagai orang yang datang ke rumpun keluarga kita, ia sama sekali tidak berhak. Semenda itu ibarat abu di atas tunggul. Ia bisa terbang kapan saja kalau ditiup angin."

\section{Local wisdom Based on Tradition or Daily Behavior within Social Intercourse}

a. Life is necessary for socialization (Keep in Social Life)

Local wisdom is reflected in the short story (cerpen) of Lontong Tek Sidar written by Indrian Koto is the habit of the community socialized to keep communication each other in Lapau (small coffee shop), while drinking coffee and also talking about rice and un-irrigated agricultural fields. This kind of such interaction is the form of the local wisdom based on habit or daily behavior, so that the Minangkabau society known as the humane society, maintaining good relations, and being part of 
social community. It is undeniable that the culture of maota (chatting) in lepau (small coffee shop), other than to foster social interaction and cultural activity is often an effective means to train the Minangkabau people for skillful talk, negotiation, argumentation, debate, and delivery of speech. Indirectly, this tradition is proved to create many figures of businessman, the press, thinker, humanist, and great politician originally from Minangkabau at the levels of national and international.

Malam, warung diisi orang tua kami. Semula hanya ngopi dan berbagi kisah seputar sawah ladang, tentang tebat yang tak berair, bukit yang terpanggang, kemarau yang tahun ini agak panjang atau tentang padi yang dihinggapi wereng, sawah di Taratak yang tak berair, laut yang tak menjanjikan sampai baju Lebaran untuk anak istri. Semua tumpah jadi satu, mulai dari rantau tempat banyak orang menggantungkan harapan sampai peruntungan dan perasaian.

b. Familiarize children with traditional food

In the short story (cerpen) Jendela Tua written by Iyut Fitra telling that an old mother is awaiting the return of her daughter and son in law from Rantau (other people home town) by preparing their favorite foods. What the mother does is the local wisdom of the Bundo Kanduang (respectful term for mother) showing how the importance is to familiarize the children with traditional food as an expression of their love for their customs and culture.

"Upik, seminggu lagi mereka pulang. Tolong peram pisang yang ditebang kemaren. Etek

Suni paling suka kolak dicampur lemang! Jangan lupa minta jagung pada Pak Simuh. Pak

Adang Kalun pasti minta jagung bakar! Kita nanti akan buat samba lado tanak buat Etek

Eti! Oya, Upik. Juga pangek ikan buat Pak Etek Rustam! Pical buat Pak Angah!” ....

c. Ramadhan (fasting month) and Lebaran (a day of celebration

at end of fasting month) as strengthening relationship.

In the short story (cerpen) of Kue Ramadan, Kue Lebaran, Kue-Kue dalam Kaleng, written by Raudal Tanjung Banua being depicted when Lebaran comes, the cupcakes are as creating relationship atmosphere. Bring the big cupcakes to the home of relatives by using rantang (set of stacked containers for bringing food/meals etc), at the time of returning home, the rantang has been filled with the money by the relatives which can be used by the children for shopping anything in the atmosphere of Lebaran. However, this kind of atmosphere is just a shadow of the past. when Kudal was still a child, he no longer found this kind of tradition. Even the people in the village no longer make the cupcakes for Lebaran because it has been replaced with canned cakes bought in the market. Moreover, bring the cupcakes to the home of relatives is not done anymore. This short story (Cerpen) showing the local wisdom in strengthening relationship is no longer respected by the young generation in Minangkabau.

Aida telah berdiri di sisi Kudal. Mereka saling pandang. Tanpa berkata-kata mereka tahu ada yang hilang. Dan Kudal, dalam sisi perasaannya yang rawan, merasa Lebaran di kampung halaman tak lebih dari kue-kue dalam kaleng. Berdentang-dentang. Mencolok, warna-warni. Tapi di sisi hatinya yang terbuka pada perubahan hidup manusia, ia berbisik rida; biarlah, bukan karena ini aku pulang. Ia melihat ibunya yang setengah bungkuk menyiapkan telekung untuk tarawih nanti malam. Tarawih malam terakhir.

\section{CONCLUSION}

Based on the study and the analysis, it is concluded that the local wisdom contents found in the modern short stories (cerpen-cerpen) written by the Minangkabau's authors are as follows. First, reflecting the local wisdom seen from philosophy of life is bravery appeared because of the truth and enemies will never be challenged, yet they will not be avoided when they come. Second, reflecting the local wisdom seen from the attitudes of social life, giving advice and moral lesson that is taking the examples of the events experienced by other people, life shall be the mutual help, economized and savings, providing assistance for construction of the public facilities, mutual help among others of the 
same village as well as environmental preservation being sacred. Third, reflecting the local wisdom seen from customs and traditions ceremony, it is the forum for local people to train their diplomatic skill and to foster principles of the mutual cooperation. Fourth, reflecting the local wisdom seen from principles, norms, and regulations which are actuated in social system; i.e. making the effort to be the person who always works hard, life shall not be proud of oneself, utilization of the environment for the benefit of life, somebody's disgrace is disgrace of all together in Suku (tribes), woman shall be honored as for continuation of descendant and as the heir to inherited wealth, and the inherited wealth bequeathed to woman, whenever it is to be mortgaged, should be discussed in advance with the mother's brother (mamak). Fifth, reflecting the local wisdom seen from tradition, daily basis social attitude within the social interaction namely; ways of living in the community, familiarize children with traditional food, convey something by expression of prohibition, as well as Ramadhan and lebaran for strengthening relationship.

\section{REFERENCES}

Agustina.2004. "Posisi Sistem Matrilineal Minangkabau dalam Kebijakan Penguasa Bangsa Indonesia" dalam Persidangan Antarbangsa Peradaban Melayu II. Malaysia: Institut Peradaban Melayu Universiti Pendidikan Sultan Idris, Tanjung Malim, Perak Darul Rizwan

Abdurrahman. 2011. Nilai-nilai Budaya dalam Kaba Minangkabau: Suatu Interpretasi Semiotik. Padang: UNP Press.

Afriyanti dkk. 2005. "Konflik Sebagai Konsep Estetika Novel-Novel Berlatar Minangkabau Periode 19201940”. Padang: Balai Bahasa Padang

Al Musanna.2011. "Rasionalitas dan Aktualitas Kearifan Lokal Sebagai Basis Pendidikan Karakter" dalam Jurnal Pendidikan dan KebudayaanVolume 17. No. 5 Tahun 2011. Jakarta: Badan Penelitian dan Pengembangan Kementerian Pendidikan

Amir, Adriyetti. 2000. "Bermuara pada Kata: Estetika Minangkabau” dalam Jurnal Antropologi. Tahun II No. 4. Padang: Laboratorium Antropologi "Mentawai".

A. Pozzolini. 2006. Pijar-pijar Pemikiran Gramsci. Yogyakarta: Resist Book.

Arifin, Zainal. 2004. Dari Dualisme Menuju Keesaan: Budaya Politik Masyarakat Minangkabau. Penelitian Hibah Bersaing, Dirjend Pendidikan Tinggi, Departemen Pendidikan Nasional RI. 2005.

Aschroft, Bill dkk. 2003. Menelanjangi Kuasa Bahasa (diindonesiakan oleh Fati Soewandi dan Agus Mokamat). Jakarta: Qalam

Asri, Yasnur. 1995. Orientasi Budaya Tokoh Wanita Minangkabau dalam Novel-Novel Warna Lokal Minangkabau Sebelum dan Sesudah Perang. Jakar: Pusat Pembinaan dan Pengembangan Bahasa

Asri, Yasnur. 2010. Sosiologi sastra: Teori dan Terapan. Padang: Tirta Mas

Asri, Yasnur. 2011. “Analisis Sosiologis Cerpen "Si Padang” Karya Harris Effendi Thahar” dalam Humaniora:Journal of Culture, Literature, Linguistics Volume 23. No. 3 Tahun 2011. Yogyakarta: FIB UGM

Atmazaki dkk. 1995. Obsesi Pengarang Pengarang Periode Balai Pustaka (Laporan Penelitian Proyek Penelitian Bahasa dan Sastra Indonesia dan Daerah, Propinsi Sumatera Barat). Jakarta: Pusat Pembinaan dan Pengembangan Bahasa.

Damono, Sapadi Djoko.2002. Sosiologi sastra. Jakarta: Gramedia

Endraswara. 2011. Metodologi Penelitian Sastra: Epistemologi, Model, Tori, dan Aplikasi: Yogyakarta: CAPS 
Ermanto.2009. "Fenomena Masyarakat Minangkabau dalam Cerpen "Si Padang” Karya Harris Effendi Thahar dan "Robohnya Surau kami" karya A.A. navis: Pemahaman Sastra dengan Pendekatan Kebahasaan" dalam Jurnal Pendidikan dan Kebudayaan Volume 15. No. 5 Tahun 2009. Padang: FBSS UNP.

Esten, Mursal. 1993. "Novel-Novel Pengarang Etnis Minangkabau dari Sisi Sosial Budaya. Jakarta: Pusat Pembinaan dan Pengembangan Bahasa

Faruk. 2005. Pengantar Sosiologi Sastra: dari Strukturalisme Genetik. Yogyakarta: Pustaka Pelajar

Gramsci, Antonio. 1985. Selection from the Prison Notebooks. Edisi dan terjemahan Quin Hoare dan Geoffrey Nowell Smith. New York.: International Publisher

Junus. Umar. 1976. "Kebudayaan Minangkabau” dalam Koentjara-ningrat (ed.) Manusia dan Kebudayaan di Indonesia. Jakarta: Djambatan Pustaka. 1986. Sosiologi sastra: Persoalan Teori dan Metode. Kuala Lumpur: Dewan Bahasa dan

Kleden, Leo. 1997. “Teks, Cerita, dan Transformasi Kreatif” dalam jurnal Kebudayaan Kalam Edisi X.

Krisna, Eva. 2004. "Roman-Roman Balai Pustaka dalam Perspektif Pascakolonial” dalam Jurnal Ilmah Bahasa dan Sastra Balai Bahasa Padang Salingka Volume 1, nomor 1, edisi Desember.

Lafevere, Andre. 1977. Literary Knowledge: A Polemical and Programatic Essay on Its Nature, Growth, Relevance and Transmition. Amsterdam: van Gorcum Assen.

Latief. Ch.N. 2002. Etnis dan adat Minangkabau: Permasalahan dan Masa Depannya. Bandung: Angkasa

Patria, Nezar dan Andi Arief. 2003. Antonio Gramsci: Negara \& Hegemoni. Yogyakarta: Pustaka Pelajar.

Putra Muniaba, I B. 2003. "Novel-novel Pramudia Ananta Toer: Refleksi Pendegradasian dan Interpretasi Makna Perjuangan Martabat Manusia" dalam Humaniora: Journal of Culture, Literature, ang Linguistic. Vol.15 No.2. Yogyakarta: FIB UGM

Rudy, Rita Inderawati. 2010. "Mengangkat Peran Sastra Lokal dengan Konsep Sastra untuk Semua bagi Pembentukan Karakter Bangsa" dalam Idiosinkrasi (Novi Anoegrajekti dll. (Ed.). Jakarta: Pusat Pengembangan Bahasa dan Budaya Universitas Negeri Jakarta dan Kepel Press.

Simon, Roger.2000. Gagasan-gagasan Politik Gramsci. Yogyakarta: Pustaka Pelajar

Suparlan, Parsudi. 2002 Menuju Masyarakat Indonesia yang Multikultural dalam www.fisip.ac.id/ antropolig/ httpdocs./ jurnal/2002/69/10brtpsu69 pdf. DIUNDU 18 September 2012

Trisman. B. 2011. "Kekuasaan dalam Dua Novel Indonesia Berwarna Lokal Minangkabau "Siti Nurbaya dan Anak dan Kemenakan": Sebuah Analisis Perbandingan yang dimuat dalam jurnal "Jantera: Jurnal kajian sastra. Jakarta: Badan Pembinaan dan Pengembangan Bahasa

Valdes, Mario J. 1997. Phenomenology Hermeneutic and The Study of Literature. London: University of Toronto Press.

Djamaris, Edwar. 2002. "Nilai budaya Keramahan dalam Sastra Rakyat Minangkabau” dalam Hasan Alwi dan Dendy Sugono. (Ed). Telaah Bahasa dan Sastra: Persembahan Kepada Prof. Dr. Anton M. Moeliono. Jakarta: Pusat Bahasa dan Yayasan Obor Indonesia.

Moleong, Lexy J. 2002. Metode Penelitian Kualitatif. Bandung: Remaja Rosda Karya.

Thahar, Harris Effendi. 2006. "Kekerasan dalam cerpen-cerpen Koran Pilihan Kompas 1992-1999: Suatu Tinjauan Struktural Genetik". Disertasi. Jakarta: Pascasarjana Universitas Negeri Jakarta.

Sarjono, Agus R. 2001. Sastra dalam Empat Orba. Yogyakarta: Bentang Budaya. 
Rasyidin, Al., Siregar, Parluhutan., Batubara, Khuzaimah. 2009. "Penyerapan Nilai-nilai Budaya Lokal dalam kehidupan beragama di Medan: Studi tentang Budaya Lokal Di Medan” dalam Afif dan Bahri, Saeful. Harmonisasi Agama dan Budaya Di Indonesia (2). Jakarta: Balitbang Kemenag.

M.S. Amir. 2007. Adat Minangkabau: Pola dan Tujuan Hidup Orang Minang. Jakarta: Mutiara Sumber Widya.

Mahayana, Maman S. 2005. 9 Jawaban Sastra Indonesia. Jakarta: Bening Publishing.

Mahayana, Maman S. 2007. Ekstrinsikalitas Sastra Indonesia. Jakarta: Bening Raja Grafindo Persada.

Moleong, Lexy J. 2002. Metode Penelitian Kualitatif. Bandung: Remaja Rosda Karya.

Navis, AA. 1986. Alam Takambang Jadi Guru: Adat dan Kebudayaan Minangkabau. Jakarta: Grafiti Press.

Navis, AA. 1999. Yang Berjalan Sepanjang Jalan. Jakarta: Gramedia Widiasarana Indonesia.

Wellek, Rene \& Austin Warren. 1995. TeoriKesusastraan. (Di Indonesiakan oleh Melani Budianta). Jakarta: Gramedia Pustaka Utama. 